\title{
Mais ou menos médicos!
}

\section{More or less physicians!}

\author{
TCBC Alberto Schanaider
}

Professor Titular do Departamento de Cirurgia da Faculdade de Medicina da UFRJ

A Saúde vai mal no Brasil e a culpa, mais uma vez, recai sobre os médicos. Para satisfazer a opinião pública, os neófitos de plantão alegam que a relação, em torno de dois médicos/1000 habitantes, afeta o bom atendimento à população, posto que, por exemplo, os EUA têm 2,7, a França 3,4 e a Argentina 3,2. Falácia, pois, o Chile, com indicador de 1,0, o Japão e o Canadá com 2,1, apresentam uma Medicina de alta qualidade. Já o Azerbaijão e o Cazaquistão, galgando 3,4 médicos/1000 habitantes, seguramente não estão melhores do que o Brasil. Tal sofisma, sob a pressão da carência de médicos em regiões prioritárias para o SUS e em face das eleições que se avizinhavam, subsidiou a publicação da Lei no 12.871 , de 2013, alcunhada de Mais Médicos e que alterou as políticas de Saúde e de Educação Médica no Brasil. Sob a eufêmica justificativa de "promover a troca de conhecimentos e experiências entre médicos brasileiros e de instituições estrangeiras", por decreto engendrou-se uma solução tampão intencional e precária, que legalizou a compra de serviços médicos "intercambistas", a imensa maioria procedente de Cuba (6,7/1000 habitantes), culminando com um reforço "mui amigo" ao PIB deste país.

Mas, a referida lei foi além. Modificou o currículo de apenas uma profissão no Brasil e incentivou a abertura de Faculdades de Medicina, desde que particulares. Em breve o Brasil superará a Índia e terá o maior número de Faculdades de Medicina no mundo. No Estado de São Paulo, que já concentra o maior número destas Faculdades no país, encontram-se 35\% dos municípios pré-selecionados para criação destas instituições e a semelhança de outros casos, diversos municípios postulantes situam-se muito próximos da região metropolitana, onde já há Faculdades de Medicina. Resumir a questão a um problema quantitativo solucionável pela abertura de novas Faculdades de Medicina é escamotear as reais intenções e passar ao largo de soluções efetivas. Jamais a ampliação numérica de médicos resolverá a dificuldade de alocação destes no interior do Brasil, pois a grande maioria, na primeira oportunidade, buscará a iniciativa privada e os convênios, haja vista comporem alternativas profissionais mais compensadoras e capazes de permitir a educação continuada e o contato com os grandes centros. O SUS não será prioridade e tão pouco haverá a competência tão necessária para a população.

Não seria mais sensato investir nas universidades públicas, que ainda congregam um corpo docente de excelência, recuperar seus hospitais universitários, reforçar o seu corpo técnico-administrativo, dar-lhes um salário digno, viabilizando a expansão de vagas nos Cursos de Medicina? Concomitantemente, faz-se mister criar uma carreira de Estado que incentive a redistribuição demográfica dos egressos dos Cursos de Medicina, tal qual à aplicada aos magistrados, com renovação e migração para grandes centros após alguns anos de carreira. Também seriam estratégias muito úteis o estímulo e a valorização do serviço voluntário, a exemplo do projeto Rondon. Mais de 100 anos se passaram desde que o educador Abraham Flexner publicou seu devastador relatório sobre a proliferação de Faculdades de Medicina no EUA e Canadá reprovando 80\% delas e causando uma reformulação, dentro do contexto da época. Estamos na contramão da história com o "Mais Médicos", privilegiando a quantidade e negligenciando a qualidade.

Lamentavelmente, no pacote para a Saúde e a Educação, novas leis foram promulgadas, dentre as quais, a que reestruturou o Plano de Carreiras e Cargos de Magistério Federal (Lei 12.772, de 28/12/2012). Esta, além de banalizar o mérito, manteve salários aviltantes, o que reforça o descaso com uma profissão tão relevante para o desenvolvimento da nação e ora transformada em um verdadeiro sacerdócio, uma profissão de fé. Portanto, no cenário do Programa Mais Médicos, não deve causar surpresa vislumbrar que nossos Mestres e Doutores em Medicina, a imensa maioria pertencente aos quadros das universidades públicas, serão contratados pelas novas instituições particulares geograficamente próximas. Isto, não só decorrerá do apelo salarial (bem acima da remuneração prevista nas inertes tabelas do serviço público), mas da incapacidade dos quadros universitários de suprirem as necessidades de formação de novos professores no país. Assim, segue-se uma lógica perversa: a universidade pública investe na longa formação de um número limitado de professores educadores e pesquisadores pós-graduados (stricto sensu) e ao final, este patrimônio humano altamente qualificado é entregue, de bandeja, para a iniciativa privada. Esta, do modo providencial, se locupleta artificialmente de horistas, de hábito sem compromissos com a pesquisa ou a produção científica, interferindo sobremaneira com a dedicação deste doente à sua instituição pública de origem, tudo isto sob os olhos condescendentes do MEC/INEP.

Ademais, há que se considerar outro aspecto digno de nota. Raras são as instituições de ensino particu- 
lares que se dispõem a arcar com a construção e manutenção de um hospital próprio e que atenda prioritariamente ao SUS, requisito essencial para a criação responsável de novas Faculdades de Medicina. Assim, pasmem colegas de profissão, de forma oportuna a lei "Mais Médicos" inverteu o ônus e gerou o Contrato Organizativo da Ação Pública Ensino-Saúde! Neste, oficializa-se, a fundo perdido, a cessão das instalações públicas municipais ou estaduais, sem contrapartidas predefinidas, para que seja viabilizada a abertura das dezenas de Faculdades de Medicina privadas, ávidas por reforçar os cofres com mensalidades de cinco a seis mil reais. Adverte-se que, as futuras mantenedoras conveniadas poderão interferir na condução das políticas de saúde pública, em face dos compromissos assumidos pelos gestores eivados de interesses políticos regionais e com o risco de instabilidades quando das mudanças dos governantes.

A maior parte da população se encontra alheia às questões público-privadas e aos imbróglios governo e associações médicas. Todavia, ainda que, momentanea- mente, sinta-se amparada pelo conhecido provérbio popular, mais vale um pássaro na mão do que dois voando, anseia por uma Medicina pública e de qualidade. Os intercambistas sequer têm o crivo da revalidação do diploma e trabalham ao arrepio da lei, mas para o governo basta o aval do parceiro ideológico. Reitera-se que a solução peremptória passa pela universidade pública e que tem seu compromisso primordial com a formação de excelência e não com o mercado de trabalho. Aos médicos competentes e habilitados não faltarão empregos, inclusive no SUS, desde que haja vontade política de se obter o melhor e não o precário, em prol do bem estar coletivo e não de um projeto hegemônico de poder.

Obviamente, para que o "Programa Mais Médicos" seja um sucesso na mídia e junto aos formadores de opinião, se incute a imagem de que este programa trará o melhor dos mundos, ao nosso país. Felizmente, a reflexão isenta e idônea sobre este tema sempre poderá ressuscitar Voltaire e seu personagem Candido, capazes de satirizar este padrão otimista incurável e irreal. 